\title{
The mineralogy study of an Anshan low grade hamatite
}

\author{
Wenli Jiang ${ }^{1, a}$, Guangquan Liang ${ }^{2, b}$, Xiwen Xia ${ }^{3, c}$,Yimin Zhang ${ }^{4, d}$, Tao Liu ${ }^{5, e}$ \\ ${ }^{1}$ Hebei Iron \&Steel Group Mining Co. Ltd. \\ ${ }^{2}$ Hebei Iron \&Steel Group Mining Co. Ltd. \\ ${ }^{3}$ Hebei Iron \&Steel Group Mining Co. Ltd. \\ ${ }^{4}$ Wuhan University of Technology \\ ${ }^{5}$ Wuhan University of Technology \\ awenlijiang718@sina.com, ${ }^{\mathrm{b}}$ liangguang987654@163.com, ${ }^{\mathrm{c} x x w}$ _619@163.com , \\ dZYm126135@126.com, etkliutao@126.com
}

Keywords: Anshan type hematite ore; mineralogy; gangue; dissemination characteristics; particle size distribution

\begin{abstract}
Through the study on technological mineralogy of anshan type lean hematite ore, proved the stope in the southern district of ore minerals in the ore is mainly hematite, limonite, magnetite, hematite, siderite images, accounts for some $40 \%$ of the content of rock,the gangue minerals are mainly quartz, orthoclase and actinolite, accounts for some $60 \%$ of the content of rock,.The central ore minerals in the ores mainly are hematite, martite, magnetite, siderite, accounts for about $42 \%$ of the content of rock, the gangue minerals are mainly quartz and chlorite. about $58 \%$ of rock content. Ore minerals in the ore mainly has illusion, hematite, magnetite and hematite siderite, accounts for about $40 \%$ of the content of rock. The gangue minerals are mainly quartz and chlorite, accounts for about $60 \%$ of the content of rocks. At the same time, find out the main chemical components, mineral composition of ore district, embedded features and disseminated extent change.
\end{abstract}

\section{Introduction}

In recent years, with the large increase in demand for iron ore, the exploitation and utilization of low grade hematite has been more and more attention. Anshan iron ore's most widely distributed, is China's important iron ore deposit, it is not only the number in the first account for around $50 \%$ of the total reserves. But due to large reserves of ore deposits usually (large and medium-sized deposit reserves accounted for $90 \%$ of this kind of deposit), a single ore body scale and large thickness, shallow, many ore deposits can strip mining, the distribution of ore deposits and more concentrated, make the class on the development and utilization of iron ore deposit accounts for a great advantage.

\section{Ore properties}

Based on the main chemical composition analysis of the stope ore samples, determine the stope ore belongs to lean hematite ore, the iron grade of about $23 \%$ on average, the content of $\mathrm{SiO} 2$ is more than $50 \%$.

Ore chemical composition as shown in table 1, as can be seen from the data in table 1, TFe, FeO and $\mathrm{SiO} 2$ content in the ore is $22.86 \%, 0.44 \%$ and $65.75 \%$ respectively, the sample is typical of anshan type lean hematite. 
Tab. 1 The analysis of the multi-elements of the raw ore

\begin{tabular}{l|ccccccc}
\hline project & $\mathrm{TFe}$ & $\mathrm{SFe}$ & $\mathrm{FeO}$ & $\mathrm{SiO}_{2}$ & $\mathrm{Al}_{2} \mathrm{O}_{3}$ & $\mathrm{CaO}$ & $\mathrm{MgO}$ \\
content & 22.86 & 20.28 & 0.44 & 65.75 & 0.34 & 0.23 & 0.046 \\
\hline project & $\mathrm{S}$ & $\mathrm{P}$ & $\mathrm{K}_{2} \mathrm{O}$ & $\mathrm{MnO}$ & $\mathrm{Na}_{2} \mathrm{O}$ & $\mathrm{TiO}_{2}$ & 烧失 \\
content & 0.010 & 0.005 & 0.04 & 0.02 & $<0.01$ & $<0.02$ & 0.58 \\
\hline
\end{tabular}

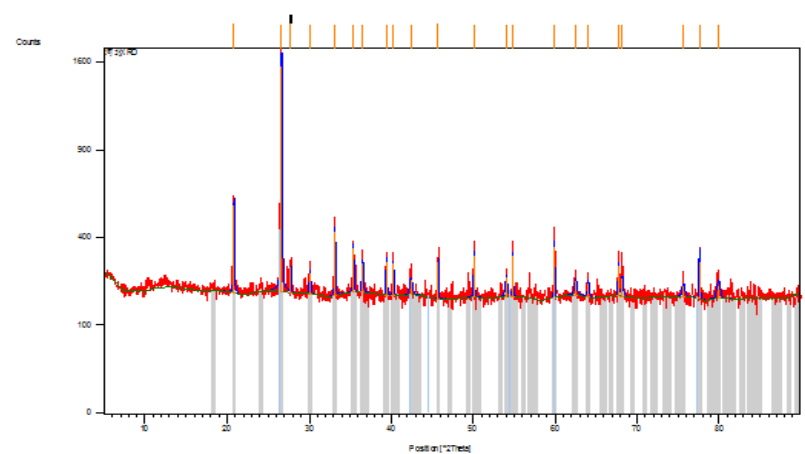

Fig.1 XRD analysis of ore

\section{Process mineralogy characteristics}

Ore minerals in the ores mainly are hematite, limonite, magnetite, hematite, siderite images, accounts for some $40 \%$ of the content of rock; The gangue minerals are mainly quartz, orthoclase and actinolite, accounts for some $60 \%$ of the content of rocks. The hematite ore for themselves and a half since the slab, size range of $0.01 \sim 0.15 \mathrm{~mm}$, mineral content is about $30 \%$ (see figure 2 a); Limonite is yellow brown soil, network of distribution in the fracture of ore vein, its content is about $5 \%$ (see figure $2 \mathrm{~b}$ ); The magnetite ore half since shape - he form of granular, granularity between $0.001 \sim 0.003 \mathrm{~mm}$, grain around edge of hematite content of about 1\%, after the portion of the magnetite and hematite, a particulate residue in hematite; Another part of the magnetite, show inclusions occur in the quartz crystal (see figure $3 \mathrm{a}$ ); The martite ore form of granular, content is about $0.5 \%$. Particle size is $0.005 \sim 0.015 \mathrm{~mm}$, assumes the palimpsest grain residue in hematite (see figure $3 \mathrm{~b}$ ). Siderite in his form of granular, content is about $1 \%$, particle size of $0.01 \sim 0.03$ $\mathrm{mm}$, a palimpsest of residual skeletal, distributed in quartz grains (see figure $3 \mathrm{c}$ ).

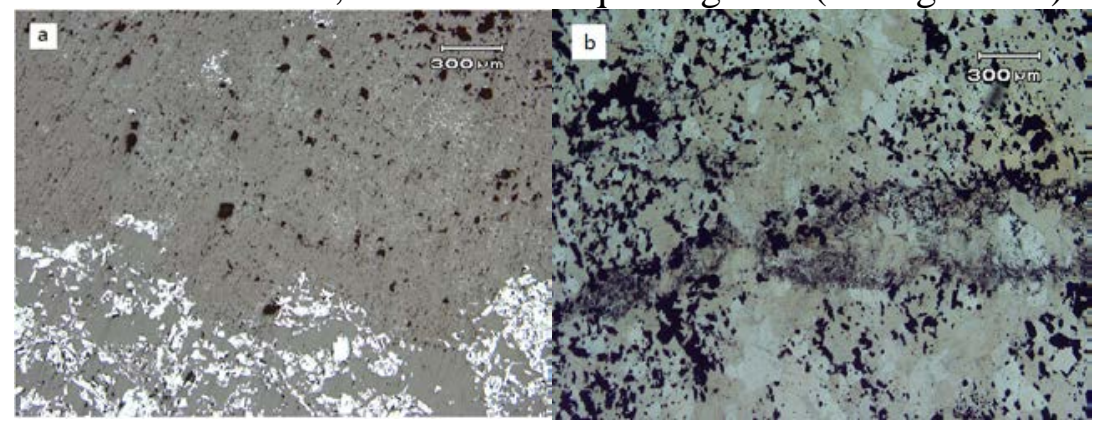

Fig.2 Distribution of hematite and limonite 


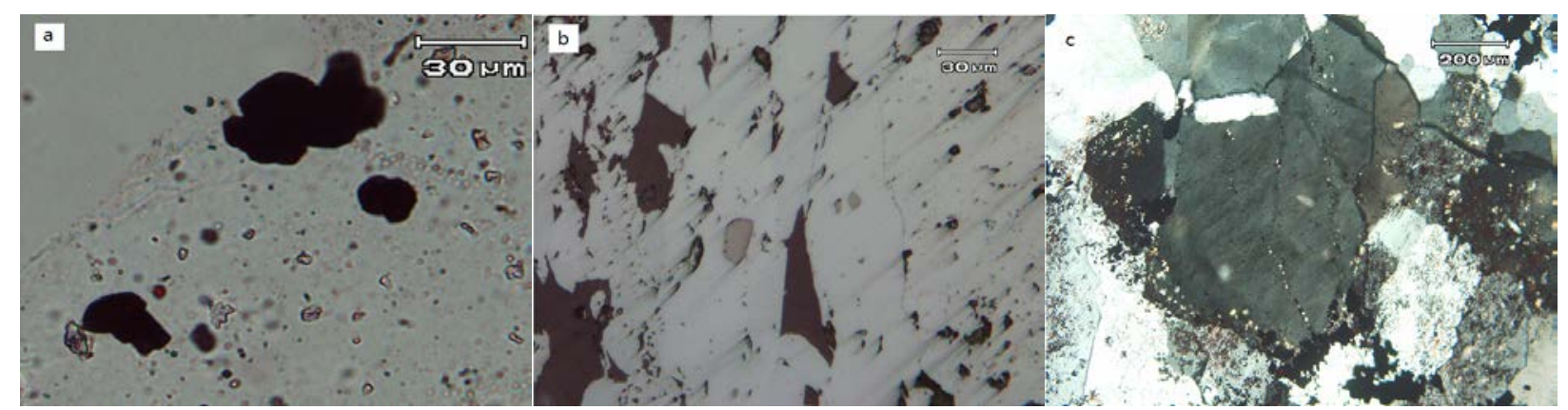

Fig.3Distribution of magnetite, hematite and siderite

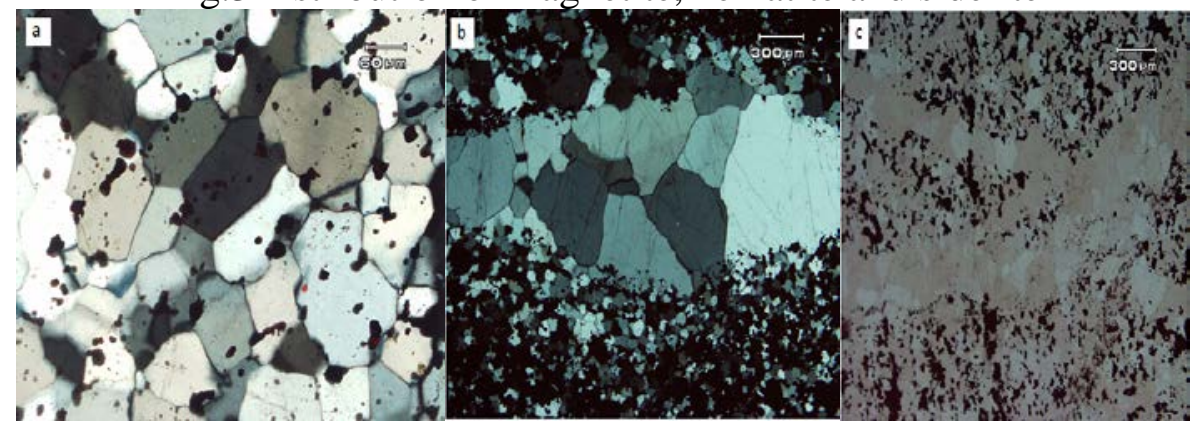

Fig.4 Distribution of quartz

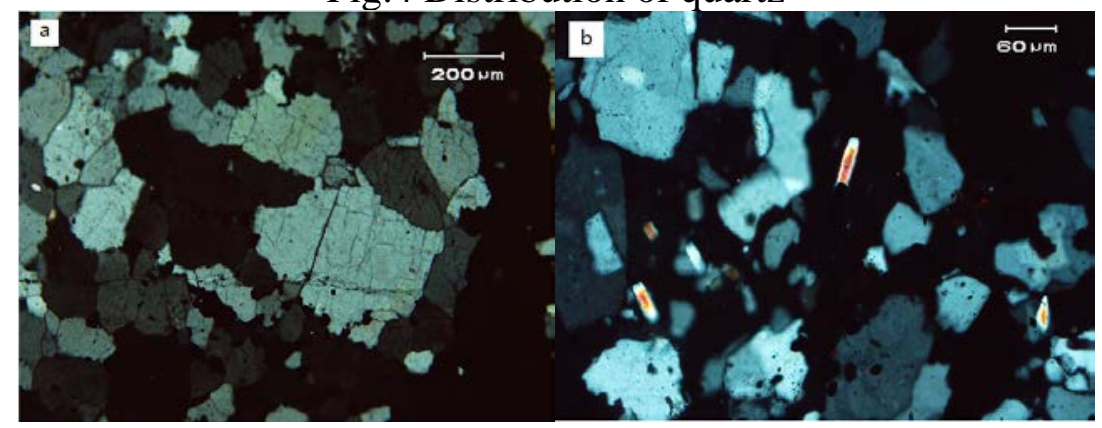

Fig.5 Distribution of orthoclase and actinolite

Ore quartz in the form of granular, is the most abundant gangue minerals, has a grid stress fringe and wavy extinction phenomenon, content is about $56 \%$.The granularity of quartz in the ore is 0.01 $\sim 0.3 \mathrm{~mm}$, give priority to with the fraction of $0.05 \sim 0.1 \mathrm{~mm}$, (as shown in figure $4 \mathrm{a}$ ); Also have the late quartz vein, net vein or lenticular output, hematite strip truncation (see figure $4 \mathrm{~b}$ and $4 \mathrm{c}$ ). Orthoclase euhedral - half automorphic granular, complete cleavage, content is about $4 \%$, grade is $0.03 \sim 0.35 \mathrm{~mm}$, obviously than quartz particle coarse (see figure $5 \mathrm{a}$ ); The ore also contains traces of actinolite, many with columnar output (see FIG. 5 b).

The central ore samples of process mineralogy research. Ore minerals in the ores mainly are hematite, martite, magnetite, siderite, accounts for about $42 \%$ of the content of rock; The gangue minerals are mainly quartz and chlorite, accounts for about $58 \%$ of the content of rocks. The hematite ore for themselves - half the plate and the form - it form of granular, size range of $0.01 \sim$ $0.20 \mathrm{~mm}$; Mineral content is about $22 \%$. In the form - half since form plate hematite, particle size within the range of $0.01 \sim 0.05 \mathrm{~mm}$ content of about $5 \%$, are scattered in the ore distribution, particle size within the range of $0.05 \sim 0.15 \mathrm{~mm}$ content of about $7 \%$ (see figure $6 \mathrm{a}$ ); Martite for half the shape - he form of granular, individual particles are euhedral crystal, particle size of 0.03 $0.15 \mathrm{~mm}$, content is about $10 \%$, under the light emitted a beige (see figure $6 \mathrm{~b}$ ); Magnetite is half the shape - he form of granular, particle size of $0.05 \sim 0.08 \mathrm{~mm}$, content is about $3 \%$. After the magnetite in hematite, residue or cracks in the hematite inclusions occur in the quartz crystal (see figure $6 \mathrm{c}$ ); Carbonate minerals in the ore is given priority to with siderite, otherwise a small amount of iron, dolomite, for granular, half the size of $0.05 \sim 0.25 \mathrm{~mm}$, content is about $7 \%$, a palimpsest residues and vein distribution (see figure $6 \mathrm{~d}$ ). 


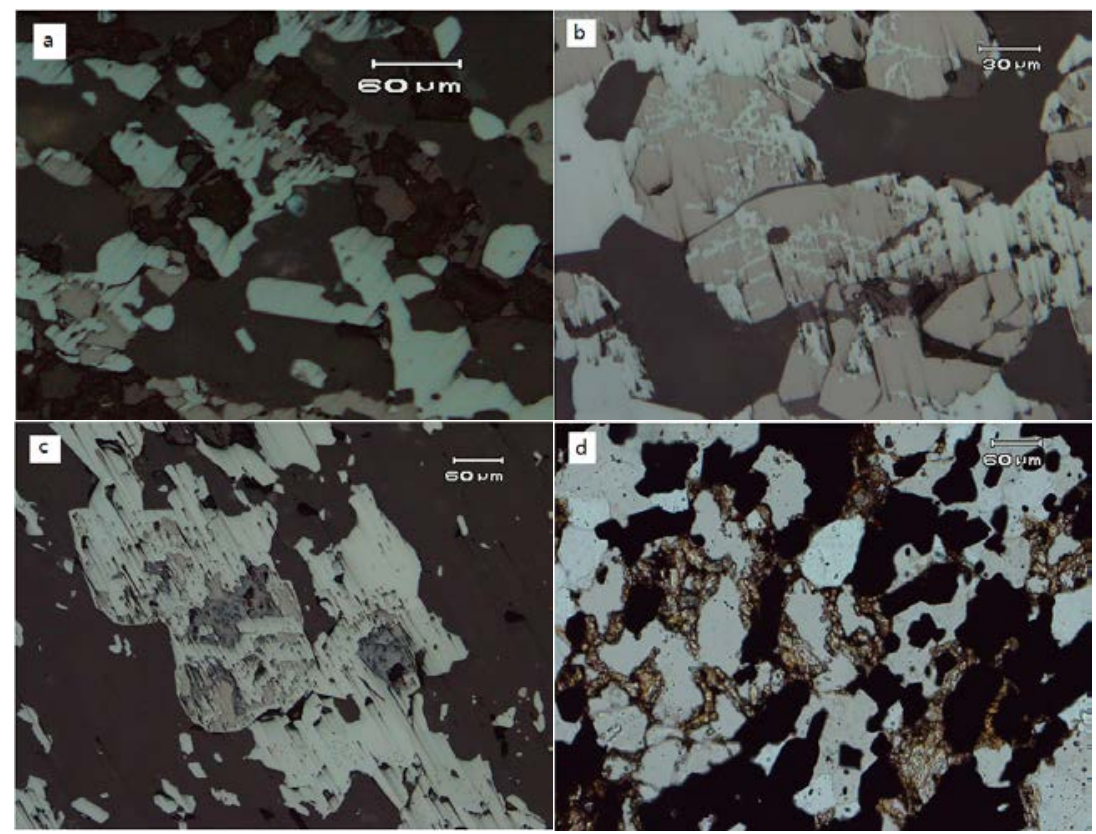

Fig.6 Distribution of hematite, false hematite, magnetite and siderite

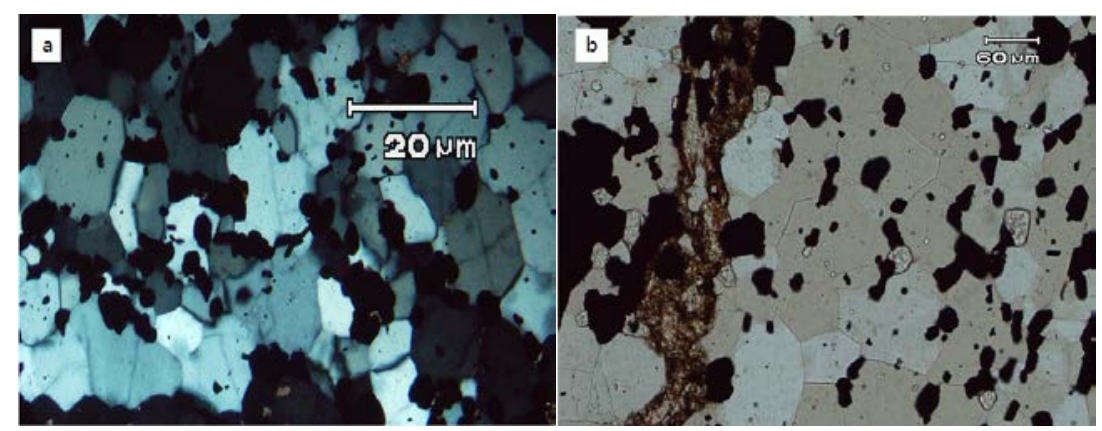

Fig.7 Distribution of quartz and chlorite

Quartz is the main gangue mineral in the ore, for his form of granular, with wavy extinction phenomenon, content is about 53\%; Particle size is $0.10 \sim 0.35 \mathrm{~mm}$ of quartz, a vein structure light color stripe, fraction of $0.05 \sim 0.15 \mathrm{~mm}$ quartz, closely associated with mineralization (see figure 7 a); Ore of chlorite to half automorphic granular, content is about $5 \%$, the granular chlorite grain size is $0.02 \sim 0.15 \mathrm{~mm}$, content is about $4 \%$ (figure $7 \mathrm{~b}$ ).

Process mineralogy study of north ore samples. Ore minerals in the ore mainly has illusion, hematite, magnetite and hematite siderite, accounts for about $40 \%$ of the content of rock; The gangue minerals are mainly quartz and chlorite, accounts for about $60 \%$ of the content of rocks. The martite ore for themselves - half automorphic granular, particle size of $0.03 \sim 0.15 \mathrm{~mm}$, content is about 20\%, the vein directional distribution, and the gangue minerals distribution in the same direction, constitute the main body of the ore belt (see figure $8 \mathrm{a}$ ); Hematite to half the shape - he form of granular, particle size of $0.05 \sim 0.20 \mathrm{~mm}$, content is about $12 \%$ (see figure $8 \mathrm{~b}$ ); Magnetite is half since form - he form of granular, particle size of $0.04 \sim 0.12 \mathrm{~mm}$, the individual particles can reach $0.5 \mathrm{~mm}$, content is about $7 \%$, after the magnetite in hematite, residue in martite or inclusions occur in the quartz crystal (see figure $7 \mathrm{c}$ ); Of siderite ore is half the shape - he form of granular, particle size of $0.05 \sim 0.15 \mathrm{~mm}$, content is about $1 \%$ (see figure $8 \mathrm{~d}$ ). 


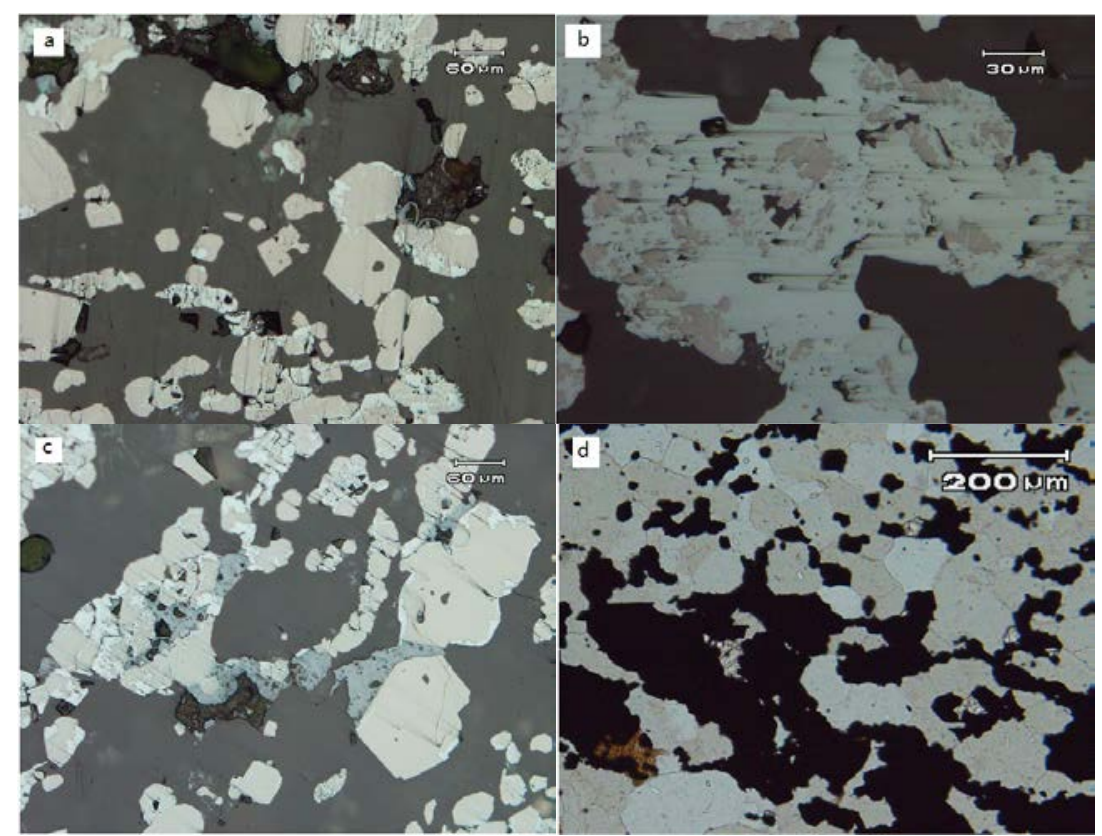

Fig.8Distribution of martite, hematite, magnetite and siderite

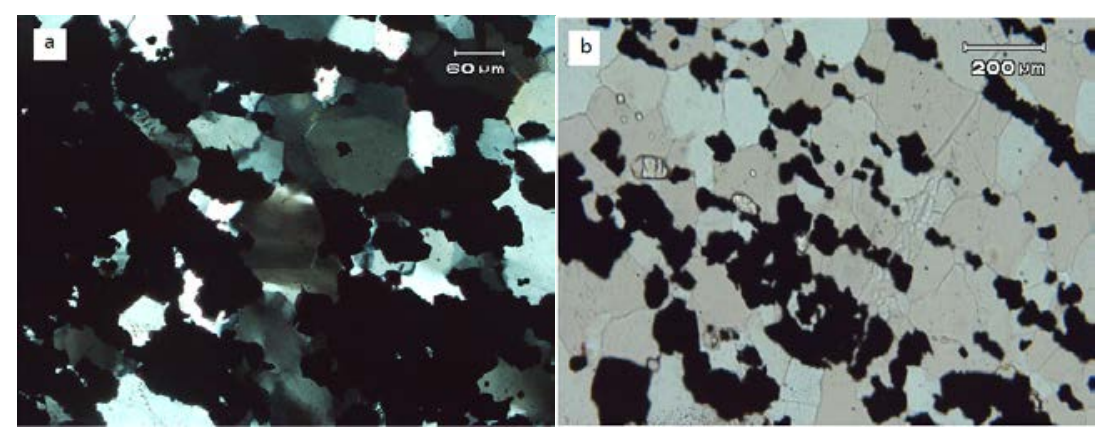

Fig.8 Distribution of quartz and chlorite

Quartz is the main gangue minerals in the ore, for his form of granular, with wavy extinction phenomenon, content is about 54\%. Particle size is $0.01 \sim 0.04 \mathrm{~mm}$ of quartz vein in light color stripe; Particle size is $0.01 \sim 0.02 \mathrm{~mm}$ quartz and closely related to mineralization (see figure 9a). Chlorite to half automorphic granular, content is about 6\%. Granular chlorite grain size is $0.02 \sim$ $0.08 \mathrm{~mm}$, content is about 3\%; Flake chlorite grain size is $0.05 \sim 0.35 \mathrm{~mm}$, content is about $3 \%$ (see figure $9 \mathrm{~b}$ ).

\section{Conclusions}

(1) core sample of process mineralogy research results show that the stope ore types for hematite quartzite or illusion hematite quartzite.

(2) in the southern district of ore minerals in the ore is mainly hematite, limonite, magnetite, hematite, siderite images, central and north ore minerals in the ore is mainly hematite, martite, magnetite, siderite, accounted for $40 \%$ of rock content, $42 \%$ and $40 \%$.

(3)The southern district of ore in the gangue minerals are mainly quartz, orthoclase and actinolite, accounting for about $60 \%$ of the content of rock, the gangue in central and north ore mainly include quartz, chlorite and accounted for about 58\% of the content of rock and 58\% respectively; Three types of ore are granular blastic texture, local variable Yu Jiegou, banded structure.

\section{References}

[1] Yang Hui-fen, Tang Qiong-yao, Wang Chuan-long, et al. Flocculation and flotation response of 
Rhodococcus erythropolis to pure minerals in hematite ores[J]. Minerals Engineering, 2013, 45: 67-72.

[2] Vidyadhar A, Neha Kumari, Bhagat R P. Adsorption mechanism of mixed collector systems on hematite flotation[J]. Minerals Engineering, 2012, 26: 102-104.

[3] Otávia Martins Silva Rodrigues, Antônio Eduardo Clark Peres, Afonso Henriques Martins, et al. Kaolinite and hematite flotation separation using etheramine and ammonium quaternary salts[J]. Minerals Engineering, 2013, 40: 12-15.

[4] Keith Quast. Flotation of hematite using C6-C18 saturated fatty acids[J]. Minerals Engineering, 2006, 19(6-8): 582-597.

[5] Pavlovic S, Brandao P R G. Adsorption of starch, amylose, amylopectin and glucose monomer and their effect on the flotation of hematite and quartz[J]. Minerals Engineering, 2003, 16(11): 1117-1122.

[6] Khangaonkar P R, Bala Subramani K J. Flocculation of hematite fines by anionic polyacrylamide polymers[J]. Minerals Engineering, 1993, 6(7): 765-774.

[7] Otávio da Fonseca Martins Gomes, Julio Cesar Alvarez Iglesias, Sidnei Paciornik, et al. Classification of hematite types in iron ores through circularly polarized light microscopy and image analysis[J]. Minerals Engineering, 2013, 52: 191-197.

[8] Jiang Wen-li. Study and discussing about hematite beneficiation process[J]. 2014,(01):109-114.

[9] Zhu Cheng-feng, Zhou Yong, Tian Yan-hong. Recleaning test of the flotation tailings of a hematite[J]. Modern Mining, 2014, (02):171-173.

[10] Xie Cheng-xiang, Li Hou-min, Wang Rui-jiang, et al. Structural characteristics of iron ore resources identified to date in China[J]. Geological Bulletin of China, 2009, (01) :80-84.

[11] Mei Guang-jun, Xue Yu-lan, Yu Yong-fu. Synthesis and application of new type cationic collector, N-dodecyl-1,3-di- aminopropanes[J]. Mining and Metallurgical Engineering, 1999, 19(4): 26-28.

[12] Cao Xue-feng. Synthesis of collectors to catch aluminum silicate minerals and studies on structure-activity relationship[D]. Changsha: Central South University, 2003

[13] HU Yue-hua, WANG Yu-hua, WANG Dian-zuo. Flotation chemistry and desilication of aluminosilicate minerals [M]. Beijing: Science Press, 2004: 117-125.

[14] F.Guan, H.Zhong, G.Y.Liu, et al. Flotation of aluminosilicate minerals using alkylguanidine collectors[J]. Transactions of Nonferrous Metals of China, 2009,19(1):228-234.

[15] Batisteli G M B, Peres A EC. Residual amine in iron ore flotation[J] Minerals Engineering, 2008,21(12-14):873-876 